\title{
Student as a Customer or Improving Students' Involvement in the Education Process
}

\author{
http://dx.doi.org/10.3991/ijep.v4i1.3002 \\ Yulia Šurinová and Martina Jakábová \\ Slovak University of Technology in Bratislava, Trnava, Slovak Republic
}

\begin{abstract}
During the process of developing new and sophisticated methods of teaching, teachers often neglect the fundamental principle of quality management, which is to adopt a customer orientation. This study proposes a new methodology to involve students in the education improvement process. The emphasis is placed on investigating student expectations, transforming student expectations into actions and a student's satisfaction survey. It may be assumed, that treating students as customers or even as a collaborative partner ensures students are involved in the education improvement process. The study is based on the assumption that the requirements of other stakeholders are met and the teacher constantly monitors the latest trends in the field of lecturing and incorporates them into lectures. To verify the study hypothesis, two surveys were conducted. Students' expectations and students' satisfaction after the education process survey data were drawn from a sample of 27 of 27 (100\% sample) students of the subject Quality Audits. Our variables within the study were related to students' satisfaction with the educational process. Building upon existing literature, the results from the research allow identification of the main strategies for students' involvement within the educational process. The presented research is intended to be a useful reference to teachers and scholars interested in continuous improvement of educational process. This paper firstly critiques the key concepts concerning customer satisfaction in terms of continuous improvement process in higher education. Then, our methodology and research approach is presented. The next part of the study discusses the results of the two surveys carried out to follow if the curriculum improvement based on students' expectation awareness can improve students' satisfaction with the educational process. Based on the surveys' findings, the paper further suggests the standardized curriculum development process implemented in basic steps of the cyclic model of the PDCA on the basis of a profound analysis of students' expectations following and fulfilment. It provides a basis for differentiating and linking of evaluation results to continuous improvement. Finally, the principal findings of the research and limitations are summarized. The proposed model of continuous curriculum improvement is applicable across a range of engineering subjects.
\end{abstract}

Index Terms - students' expectations, students' satisfaction, student's involvement, continuous improvement, continuous curriculum improvement process.

\section{INTRODUCTION}

"Continuous improvement in all aspects of the business is essential for meeting the challenge of today's environments. One increasingly popular strategy for enabling continuous improvement is through mobilizing a high level of involvement of the workforce in sustained incre- mental problem-solving" [2]. "In intangible terms in higher education, staff assets include the informal communications across the organization, its performance culture, the attitudes and willingness of staff to deal with students and their problems, the embedded knowledge of "how the university works" (which typically varies significantly to the recorded, official image in most organizations), and the network of professional contacts both internal and external to the organization" [3]. The key is to develop an understanding of "what works" and what students want. Whilst trying to develop new sophisticated methods of teaching and build a ,perfect" education system teachers sometimes forget to adopt the first fundamental principle of quality management, which is the customer orientation. "Policies issued to implement educational changes for education quality often fail because of lack of comprehensive understanding of the complex nature of education quality in schools or higher education institutions" [7]. From one perspective Hoffman [4] investigated the reasons why institutions of higher education should not regard the student as the customer. "It is proposed that differences between profit-seeking enterprises and colleges and universities preclude the customer-focus from being an entirely useful one. In fact, the student-asa-customer paradigm may cause institutions to concentrate on short-term, narrow student satisfaction, rather than meeting the long-term needs of an entire range of stakeholders". Hoffman suggested treating the student as collaborative partner [4]. In contrast treating students as customers ensures they become engaged in the education improvement process. It is also necessary to consider the wide range of stakeholders involved to the education process. "The closer leaders are to the core business of teaching and learning, the more likely they are to make a difference to students" [5]. Yin Cheong Cheng and Wai Ming Tam [7] in their study "Multi-models of quality in education" introduced seven models of quality in education: "the goals and specifications model; the resources input model; the process model; the satisfaction model; the legitimacy model; the absence of problems model; and the organizational learning model. The satisfaction model cannot be implemented without being aware of the expectations of those who have to be satisfied".

\section{RESEARCH METHODOLOGY}

It is widely accepted that the most effective way to understand students' expectations and requirements is to obtain feedback regarding their studies. There can be no doubt that by understanding students' expectations, teachers can "act" upon implementing the core expectations. In order to verify this hypothesis, two surveys were conducted. The surveys were carried out as part of the subject 
quality audits for the taught Master's degrees at the Institute of Industrial Engineering, Management and Quality at the Faculty of Materials Science and Technology STU in Trnava. In total 27 students specialising in Products Quality Engineering participated in the survey. The first survey was focused on identifying what students expect from the subject. The second survey focused on measuring whether students were satisfied with the subject; meanwhile opportunities for improvements were explored. The subject of quality auditing is also one of the core tools for future quality engineers and a quality engineer must be aware of customer needs. Thus, students in this specialization are required to have deep understanding of customer satisfaction issues and at the same time must learn to express their suggestions for improvement, while they are aware of the consequences and implications of this research.

In general, the question of student involvement in the learning process is associated with the phenomenon of leadership. Some authors directly link the degree of involvement of students with the ability of a teacher as a leader to actively engage students in the learning process. However, there is no doubt that a good leader is aware of the stakeholders' requirements and effectively works with these demands. The purpose of this study is to investigate whether understanding and focusing on meeting the requirements of students helps to increase student satisfaction with the subject and increases the level of students' involvement in the learning process.

The study's hypothesis was as follows: "Student's requirements understanding leads to students' satisfaction and involvement".

In order to verify the hypothesis various research methods were used. A literature search involved reviewing available materials. To determine the students' expectations and evaluate their satisfaction the survey method combining with interviews were used. The first survey was carried out at the beginning of the education process (expectations awareness) and the second one was conducted after the education process (satisfaction evaluation). The second method was a series of depth interviews conducted with students, which is a valuable technique to obtain information during the initial stages of a research project. It was used to gather information that is not publicly available, or that is too new to be found in the literature. After measurement of the gathered the information, an analysis was conducted. To formulate conclusions, the synthesis method was adopted to develop the standardized subject continuous improvement cycle. This concept is underlined throughout as a key to discovering how teachers and students gain fulfilment from their educational experiences.

\section{ANALYSIS AND FINDINGS}

"Demands for institutional accountability in higher education have been increasing and have led to greater attention to the evaluation of teaching, the assumption being that improved teaching will result in enhanced learning" [10]. The author expressed clearly, that it is necessary to create a comprehensive evaluation model to develop and encourage the collection of evaluated data from a variety of sources concerning the quality and impact of teaching: the teacher; student learning outcomes; student experience; and the teacher's peers. During the study there were two evaluation models created: the first one to identify student's expectations and the second one to follow whether the students' expectations were met.

To ensure accuracy, the results were verified based upon researched best practice in the field of "Quality Audits". It is evident that subjects regarding emerging managerial skills and positive attitude to continuous improvement are now an integral part of modern engineering education. A quality audit is one of the core improvement tools of modern quality management. Positive attitude towards audits organizations ensures long-term prosperity. For this reason it is extremely important to sufficiently teach this subject and implement and to apply basic principles of quality management throughout the educational process.

To identify what future quality engineers expect from the Quality Audits, the first survey was conducted. The results are presented in Figure 1. The graph shows that 25 out of 27 students expected to acquire new knowledge with the guidelines to practice. 18 out of $27(67 \%)$ students indicated that they expected contact with practice, e.g. practical advices for their future career. Surprisingly no one expected space for creative self-expression during projects' elaboration. Few students considered important repeating acquired knowledge from the completed subjects. A few students $(5 / 27)$ considered it a priority to easily obtain study credits.

Considering the first survey results and to meet students' expectations the subject's content from the previous year was analysed and adapted according to the students' needs: the subject's content was enriched with information and experience necessary for students. The adapted subject's program is shown on the Table 1.

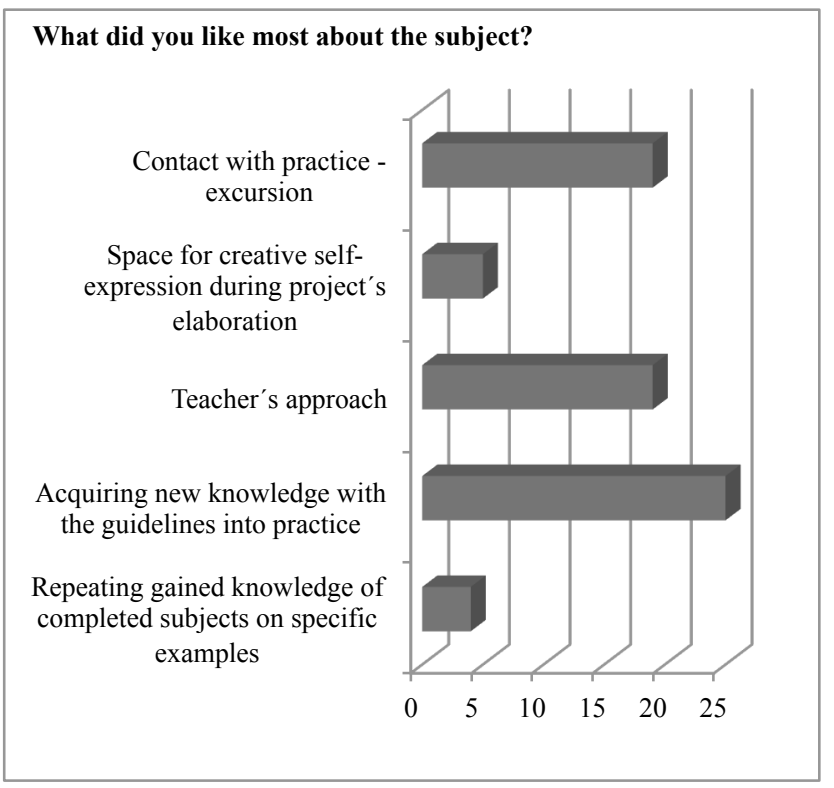

Figure 1. Students' Expectations [own source, 2013] 
TABLE I.

ADAPTED SUBJECT'S SCOPE [OWN SOURCE, 2013]

\begin{tabular}{|l|l|}
\hline \multicolumn{1}{|c|}{ Year 2012 } & \multicolumn{1}{|c|}{ Year 2013 } \\
\hline $\begin{array}{l}\text { the theoretical basis for auditing: } \\
\text { repeat } 8 \text { principles of quality } \\
\text { management, process approach, } \\
\text { the requirements of ISO } \\
19011: 2011\end{array}$ & remains the same \\
\hline $\begin{array}{l}\text { analysis of standard ISO } \\
19011: 2011\end{array}$ & $\begin{array}{l}\text { practical advice on Best Practic- } \\
\text { es, audits in the automotive }\end{array}$ \\
\hline no excursion to enterprises & $\begin{array}{l}\text { excursion to the enterprise: } \\
\text { introduction to the documenta- } \\
\text { tion in the process of auditing } \\
\text { and sample audit in the work- } \\
\text { place }\end{array}$ \\
\hline $\begin{array}{l}\text { separate processing project and } \\
\text { presentation }\end{array}$ & $\begin{array}{l}\text { possibility to use specific stand- } \\
\text { ards for automotive }\end{array}$ \\
\hline
\end{tabular}

"The real aim of every business is not to supply, not to sell, or not to serve, but rather to satisfy the needs that drive customer satisfaction. Organizations able to rapidly understand and satisfy customers' needs make greater profits than those which cannot" [12]. Thus, customer satisfaction must not only be conceived as a key differentiator from competitors, but also needs to be considered a business philosophy that tends to the creation of value for customers, anticipating and managing their expectations and demonstrating the ability and responsibility to satisfy their needs. In fact, enterprises exist because they have a customer to satisfy. The concept of student satisfaction is derived from that of customer satisfaction. Zeithaml, Parasuraman, and Berry [13] highlighted how the concept of satisfaction can be measured by the gap between consumption experiences and expectations. "The customer satisfaction concept needs to be modified to be applied to educational services in order to comprise constitutional amendments, administrative policies, and educational goals" [14]. Monitoring the satisfaction of students requires that educational institutions continuously collect data and information about what students think about the services provided. Universities can employ information on student satisfaction to better understand student needs and make changes in their offers to meet students' desires. Having learned students' expectations and having adapted the subject's scope to their needs and expectations, the next aim was to check whether students were satisfied with the subject and if the subject's scope met their expectations. Students also had the opportunity to define areas for improvement in the future.

Figure 2 highlights all the positives about the subject from the students' perspective. Students were satisfied with the level of acquired knowledge related to practice $(25 / 27)$, they (18/20) also enjoyed the excursion which gave them an opportunity to view the audit process in practice and finally they were responsive to the teacher's approach. These data confirm the argument, that student evaluations are most valuable when used to improve teaching [11].

Students were also asked to rate the importance of each aspect of the course. Figure 3 shows how important (from the student's perspective) each aspect of the subject was at the beginning of the first course and after the last course. Apart from the area referred to as 'Project Elaboration', in all other areas the requested improvement was adopted. The results were reached due to the fact that, during the course the importance of each course's step was empha-

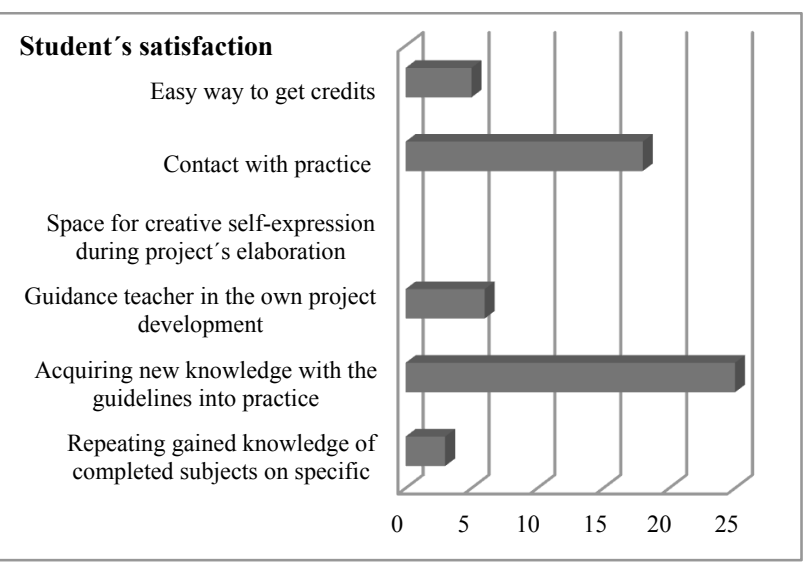

Figure 2. Students' Satisfaction [own source, 2013]

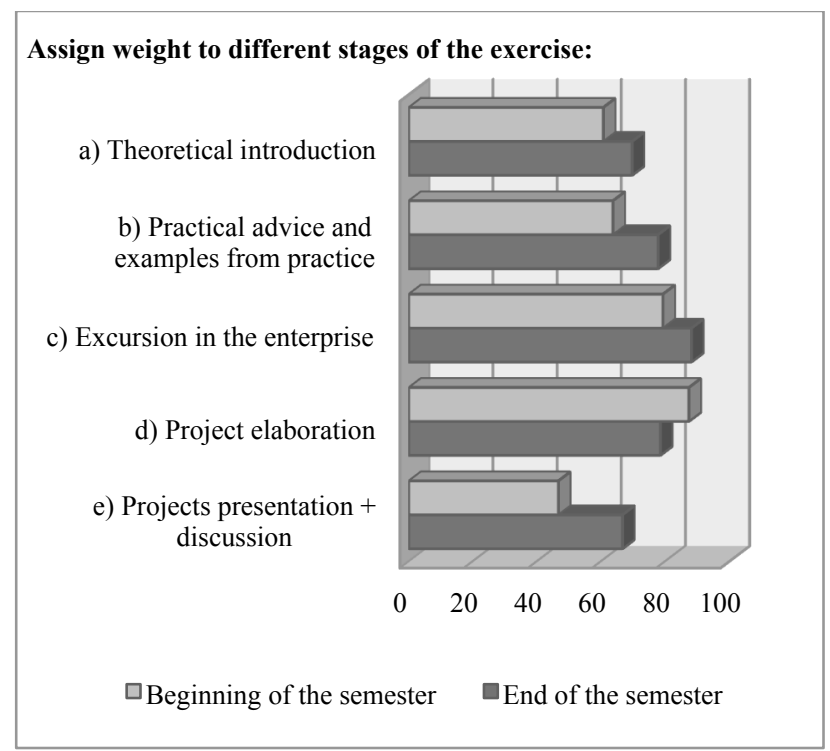

Figure 3. Importance of the Course Parts [own source, 2013]

sized. Additional results were achieved in the area of "Project Presentation", in terms of students understanding of the importance to not only create the projects, but also to create presentations and effectively present the results. The least positive result was in the area of "Project Elaboration", which was negatively affected by the short duration of the subject in the context of future quality engineers or managers (only 7 weeks of semester for the $2^{\text {nd }}$ year students of Master's degree).

Finally, students were asked to express their suggestions for improving the course - see Figure 4. It is now important to emphasize, that all the suggestions will be reviewed and integrated into the subject's curriculum for the next academic year (2013/2014).

Besides the survey, the personal interviews with the students were also extremely valuable. All the areas of the survey were discussed with students and the outcomes of the discussion will be considered within the new subject curriculum in the academic year 2013/2014. Considering the students' suggestions for improvement (range of practice) the students' projects are planned to be elaborated for the concrete process in the concrete organization. Moreover, the best students will be able to engage in audits within industrial organization as observers. 
Where do you see opportunity for improvement?

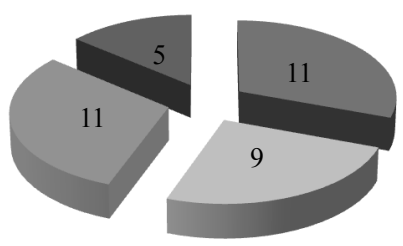

Consistency of exercise content and lectures content

Range of practice small range in relation to importance of the subject

Enrichment of presentations with demonstrations (eg. video materials)

- Others

Figure 4. Students suggestions for improving the subject [own source, 2013]

\section{A. Standardized subject continuous improvement}

Treating students as customers or even as collaborative partners means understanding their requirements and expectations, communication throughout the education process and transformation of the obtained information into understandable and specific actions. Careful observations confirmed that customers are satisfied only if teacher is aware of their requirements and strives to meet them in an adequate way. According to Deming ,It is not enough to do your best; you must know what to do, and then do your best". The same is applicable for the education process: we must know what to teach and then do our best in the teaching process. In doing so a teacher performs a model of behaviour of modern industrial engineer with respect to continuous improvement. Continuous improvement is a never-ending process and searching for improvement should not stop, it is absolutely essential to involve students and to include their contribution to the improvement process. Synthesizing the required results, Figure 5 below shows the standardized continuous process of subject improvement which is widely applicable to different areas of engineering studies.

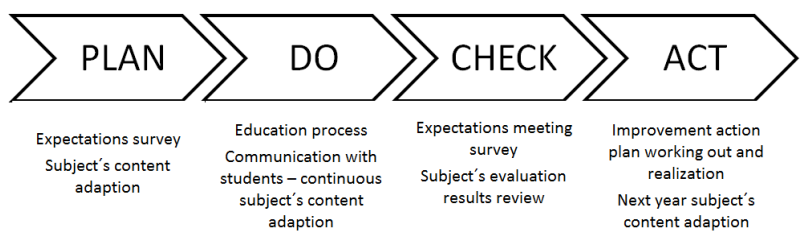

Figure 5. Standard Continuous Curriculum Improvement Process [own source, 2013]

The proposed model delineates a set of core principles from the Japanese Kaizen concept and illustrates the contingent nature of the curriculum continuous improvement process. The intent of this study was to strengthen the professional role teachers' play in curriculum planning and development, a process central to teacher leadership and responsibility.

\section{CONCLUSIONS}

"Student learning is primarily a function of teacher centric and institution centric processes. For sustained gains in student learning, it is important to have a feedback mechanism between 'teaching' and 'assessment', which we have addressed through the adoption of continuous improvement philosophy" [6]. Our survey confirmed the hypothesis set at the beginning of the paper: student's requirements understanding leads to students' satisfaction and involvement. Students who participated in the survey were satisfied with the subject's content and interpretation as well as teacher's approach - which was validated in the subject's evaluation which computer aided by the academic information system. Based on the survey results, the author does not agree with the approach that that students' prefer to adopt the 'least effort' approach and their preference is not always what is best for them. Some authors believe that the approach of treating students as customers is valid for private non-academic courses. But there now can be no doubt, that this type of education more efficiently involves students in the education process.

The study demonstrated the effectiveness of the application of continuous improvement theory for teaching processes particularly in attaining student learning related goals by the adoption of plan, do, check and act (PDCA) cycle. The study shows how teachers can improve their own subjects using widely known tools and principles. Following latest trends in the field of lecturing, knowledge of students' requirements as well as their integration into subject's content directly influences the subject's efficiency. It is hard to change the existing system. Mark Twain said: „Continuous improvement is better than delayed perfection". Teachers are able to improve educational process by means of their subjects' improvement without waiting for ,perfect" system creation. The broad aim of the research was to emphasize the teacher's approach importance to satisfy students' needs and to make learning process more efficient. Finally this paper described the development of a model for integrating student evaluation into continuous curriculum improvement process.

\section{REFERENCES}

[1] Stabile, Christopher, and William F. Ritchie. (2013). Clarifying the Differences between Training, Development, and Enrichment: The Role of Institutional Belief Constructs in Creating the Purpose of Faculty Learning Initiatives. New Directions for Teaching and Learning 2013.133 p., 71 p.-84 p. http://dx.doi.org/10.1002/ t1.20047

[2] Bessant, John, and Sarah Caffyn. (2003). High-involvement innovation through continuous improvement. International Journal of Technology Management 14.1: 7-28. http://dx.doi.org/10.1504/ IJTM.1997.001705

[3] Rees, Stephen John, and Huw Protheroe. (2009). Value, Kaizen and Knowledge Management: Developing a Knowledge Management Strategy for Southampton Solent University. The Electronic Journal of Knowledge Management 7.1: 135 p.-144 p.

[4] Hoffman, K. Douglas, and John EG Bateson. Essentials of services marketing. Orlando, FL: Dryden Press, 1997.

[5] V. Robinson: School Leadership and Student Outcomes: Identifying What Works and Why? Australian Council of Leaders, Melbourne (2007)

[6] Vanteddu, Gangaraju, and Chellappan Somarajan. (2012). A'continuous improvement'-based approach for the assessment of student learning. International Journal of Information and Operations Management Education 5.1: 86 p.-103 p.

[7] Cheng, Yin Cheong, and Wai Ming Tam. (1997). Multi-models of quality in education." Quality assurance in Education 5.122 p.-31 p. http://dx.doi.org/10.1108/09684889710156558

[8] Berger, Anders. (1997). Continuous improvement and: standardization and organizational designs. Integrated manufacturing systems 8.2: 110 p.-117 p.

[9] Smith, Calvin. (2008). Building effectiveness in teaching through targeted evaluation and response: Connecting evaluation to teach- 


\section{SHORT PAPER}

\section{STUDENT AS A CUSTOMER OR IMPROVING STUDENTS' INVOLVEMENT IN THE EDUCATION PROCESS}

ing improvement in higher education. Assessment \& Evaluation in Higher Education 33.5: 517 p.-533 p.

[10] McAlpine, Lynn, and Ralph Harris. (2002). Evaluating teaching effectiveness and teaching improvement: A language for institutional policies and academic development practices. International Journal for Academic Development 7.1: 7 p.-17 p.

[11] Seldin, Peter. (1989). Using student feedback to improve teaching. New Directions for Teaching and Learning 1989.37: 89-97. http://dx.doi.org/10.1002/t1.37219893711

[12] Barsky, L. Nash. (2003). Customer satisfaction: Applying concepts to industry-wide measures. The Cornell Hotel and Restaurant Administration Quarterly, 44 (4), pp. 173 p.-183 p.

[13] V.A. Zeithaml, A. Parasuraman, L.L. Berry „Delivering quality service“" The Free Press, New York (1990)

[14] M.A. Stone, S. Thomson (1987). „How far can marketing be applied within the further education sector?" The Quarterly Review of Marketing, Autumn, pp. 16-19

[15] Gandolfo Dominici, Federica Palumbo „How to build an elearning product: Factors for student/customer satisfaction" Business Horizons, Volume 56, Issue 1, January-February 2013, Pages 87-96 http://dx.doi.org/10.1016/j.bushor.2012.09.011

[16] Jakábová, M. and Fojtíková, A. (2008). Vzdelávanie $v$ oblasti projektového manažmentu. Education in the field of project management. In: Rozvoj akademického vzdelávania pre potreby verejnej správy: Zborník príspevkov z vedeckého seminára, Bratislava, 24.apríl 2008. - Bratislava: Vysoká škola ekonómie a manažmentu verejnej správy v Bratislave, 2008. - ISBN 978-80-89143-68-9. S. $141-148$

\section{AUTHORS}

Yulia Šurinová, MSc. Eng., PhD. is a junior lecturer and young researcher in the Slovak University of Tech- nology in Bratislava, Faculty of Materials Science and Technology in Trnava, Institute of Industrial Engineering, Management and Quality, Paulínska 16, 91724 Trnava, Slovakia. Having required practical experience in quality management in industrial enterprises she currently deals with quality management systems, quality audits, total quality management and specificities of quality management in automotive production (e-mail: yulia_surinova@stuba.sk).

Martina Jakábová, MSc. Eng., PhD. is a senior assistant and vice-director for entrepreneurial activity, lifelong education and public relations in the Slovak University of Technology in Bratislava, Faculty of Materials Science and Technology in Trnava, Institute of Industrial Engineering, Management and Quality, Paulínska 16, 91724 Trnava, Slovakia. She has expertise in the field of project and process management and information technologies. She has dealt with analysis, implementation, optimization of the projects and processes in organizations, while actively participating in the projects (e-mail: martina.jakabova@stuba.sk).

This paper is a part of submitted ESF project (ITSM 26110230055) "The Identification of Sustainable Rationalization and improvement of Industrial Management degree program to support career guidance". Submitted, 11 July 2013. Published as resubmitted by the authors on 01 September 2013. 